\title{
Genetic characterization of fragmented populations of Cinchona officinalis L. (Rubiaceae), a threatened tree of the northern Andean cloud forests
}

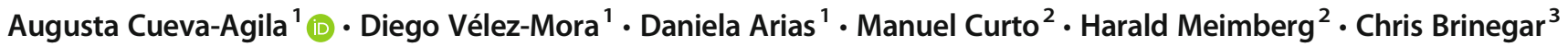

Received: 28 June 2019 /Revised: 1 October 2019 / Accepted: 4 October 2019 / Published online: 29 November 2019

(C) The Author(s) 2019

\begin{abstract}
Cinchona officinalis L., a tree species endemic to the cloud forests of the northern Tropical Andes, has suffered from historical bark harvesting for extraction of antimalarial compounds and has also experienced recent demographic losses from high rates of deforestation. Most remnant populations are found in severely degraded habitat on the edges of pastures while a minority are protected in private reserves. The goals of our research were to assess the genetic diversities of fragmented populations of C. officinalis in the Loja province of southern Ecuador, characterize their phylogeographic distribution with respect to the region's complex topography, and identify priority populations for conservation. Five nuclear microsatellite loci and the chloroplast rps 16 intron were used to analyze six populations. Moderate levels of genetic diversity were found in all populations although the more remote southern population (Angashcola) had slightly higher heterozygosity and allelic richness. There were no indications of recent genetic bottlenecks although an rps 16 intron haplotype was fixed in four populations. Genetic distance analysis based on microsatellite data placed the four easternmost populations in the same clade while the Angashcola population was the most divergent. Also, the most frequent rps 16 intron haplotype in Angashcola was not found in any other population. Although each of the studied populations should be protected from further deforestation and agricultural expansion, the Angashcola population deserves highest conservation priority.
\end{abstract}

Keywords Cinchona officinalis $\cdot$ Tropical Andes $\cdot$ Microsatellites $\cdot$ rps 16 intron $\cdot$ Genetic diversity $\cdot$ Ecuador

\section{Introduction}

The Tropical Andes biodiversity hotspot is home to at least 20,000 endemic plant species (Myers et al. 2000). In Ecuador, this hotspot is composed primarily of the Eastern Cordillera

Communicated by F. P. Guerra

Electronic supplementary material The online version of this article (https://doi.org/10.1007/s11295-019-1393-y) contains supplementary material, which is available to authorized users.

Augusta Cueva-Agila

acueva@utpl.edu.ec

1 Departamento de Ciencias Biológicas, Universidad Técnica Particular de Loja, Loja, Ecuador

2 Insititute for Nature Conservation Research, University of Natural Resources and Life Sciences, Vienna, Austria

3 Division of Natural Sciences, University of Maine Farmington, Farmington, ME, USA
Real montane forests ecoregion which contains up to 8000 plant species (Richter et al. 2009) and is dominated by evergreen broad-leaved forest communities, including cloud forests at higher elevations. Southern Ecuador, particularly the provinces of Loja and Zamora-Chinchipe, has especially high species richness (Brehm et al. 2008).

Patterns of plant diversity are determined by multiple interrelated factors (Kreft and Jetz 2007). In southern Ecuador, the high vascular plant diversity can be explained by its special and complicated topography with high mountains, valleys, and inter-Andean region (Richter 2003). The specific air circulation patterns differ between the western and eastern mountain ranges, conferring specific and heterogeneous precipitation patterns to each side and between them, as well. The existence of multiple dry and wet areas has resulted in many different ecosystems suitable for multiple species (Richter and Moreira-Muñoz 2005). In addition, southern Ecuador is located within the Andean Depression, the lowest part of the Andean mountain range where the northern and central Andes merge (Richter et al. 2009). This low elevation might 
have allowed contact of coastal and Amazonian species, thereby further increasing the region's biodiversity (Beck and Richter 2008).

Furthermore, there are other evolutionary forces such as ecological-geographical barriers that could explain the diversity of this region (Hughes and Eastwood 2006; Prieto-Torres et al. 2018). The convergence of the eastern and western cordilleras of the Andes and the repeated Pleistocene glacial and interglacial periods in the Ecuadorian Andes would have created several physical and climatic barriers to migration, including mountain ranges and low valleys in the Loja and Zamora-Chinchipe provinces that likely contributed to the current species richness of the region (Jørgensen et al. 1995; Richter et al. 2009). Such impediments to gene flow raise the possibility that populations may have existed in isolation long enough for significant genetic divergence to have occurred. In addition, fluctuations in population size and repeated bottlenecks associated with ongoing Pleistocene climatic instability may be important factors that have affected the genetic diversity of populations inhabiting this region (Prieto-Torres et al. 2018).

Habitat conditions can also affect the genetic flow between populations (Coates et al. 2003). Deforestation and habitat fragmentation have been the main pressures that are affecting the diversity of tropical forests (Hansen et al. 2013; Lambin et al. 2003; Macedo et al. 2012; Tapia-Armijos et al. 2015). Also, some species have suffered from selective logging that intensifies the impacts on demographic structure of trees (Broadbent et al. 2008; Inza et al. 2012). Beginning in the late 20th century, the clearing of nearly half of the native forests in southern Ecuador for pastureland and plantation silviculture (Tapia-Armijos et al. 2015) further reduced and fragmented the remaining forests, many of which are on private, unprotected land. The combination of these disturbances in the landscape can reduce the forest into small remnants and can lead to reduction in connectivity of populations with concomitant decrease in gene flow, thus increasing genetic differentiation and reducing genetic variability (Aguilar et al. 2008; Cascante et al. 2002; Lowe et al. 2005).

Cinchona is a genus of the Rubiaceae family known for its medicinal importance as a source of quinine and other alkaloids that are present in different quantities in its 23 species. Cinchona is widespread throughout the central and northern Andes with a noticeable center of diversity just north of the Huancabamba Deflection in southernmost Ecuador. Most species of the Cinchona genus seem to have fairly restricted distributions, and although they have a tendency to hybridize, their ranges do not typically overlap (Andersson 1998).

Cinchona officinalis was the first species of the genus to be described in detail (Andersson 1998). The species was named by Linnaeus in 1753 based on a specimen collected in Cajanuma (near Loja, Ecuador) in 1737 by La Condamine (Garmendia 2017). The distribution of $C$. officinalis is limited only to a small area in the Andean cloud forest. In Ecuador, C. officinalis $\mathrm{L}$. is found in the southern provinces of Loja, El Oro, Cañar and Azuay at 1700-3100 m a.s.l. (Andersson 1998). Brako and Zarucchi (1993) also reported the occurrence of $C$. officinalis in the northern Andes of Peru. The growth form of the species can be shrubby, but small trees up to $6 \mathrm{~m}$ tall are more common. Cinchona officinalis has distylous pinkish or purplish tubular flowers' (Andersson 1998) that promote outcrossing by hummingbirds (Tropicos 2018). Its small wind-dispersed winged seeds are enclosed in capsules (Andersson 1998).

During the conquest of the Americas in the 16th and 17 th centuries, Spanish missionaries learned of Cinchona bark's medicinal properties from indigenous tribes and discovered its effectiveness in the treatment of malaria (Jaramillo-Arango 1947). Therefore, C. officinalis was probably an important source of quinine and other alkaloids in the early years of Cinchona harvesting but became less so as its small native populations near the early Spanish settlement of Loja were exhausted by the mid-18th century (Gray 1738). Early bark harvesting methods were typically fatal to the trees (Arias 2017). Other, more abundant, Cinchona species were exploited over the next 200 years (Andersson 1998; Martin and Gandara 1945). Once Cinchona plantations were established in Asia in the 19th century, the pressure on native Andean populations eased, but a second round of harvesting occurred during World War II when the Allied quinine source was cut off from the Dutch East Indies and tens of millions of pounds of Cinchona bark were exported to the United States (Hodge 1948; Cuvi 2011). The oldest map of Cinchona distribution in Loja is a hand-painted map deposited in the Archivo General de Indias, in which bark collectors and Cinchona trees are depicted (Crawford 2016). According to this map, Cinchona trees were widely distributed in the mountains of the Loja province. However, the past overharvesting and the high rates of deforestation in southern Ecuador in recent decades (Tapia-Armijos et al. 2015) have threatened C. officinalis.

Determining the genetic composition of remaining populations of $C$. officinalis can help plan effective conservation and reforestation measures for this important species. The main objectives of this research were (i) to characterize the genetic diversity of the remnant $C$. officinalis populations in Loja province of southern Ecuador by nuclear and chloroplast DNA analysis, (ii) to test our hypothesis that barriers to migration and gene flow in southern Ecuador will have resulted in divergent populations of $C$. officinalis in the more geographically 
isolated parts of its distribution, and (iii) to identify priority populations for conservation.

\section{Materials and methods}

\section{Population descriptions, sample collection, and DNA isolation}

Six populations of $C$. officinalis were sampled from forest fragments in southern Ecuador (Fig. 1), all within Loja province. The majority of samples were collected from trees that probably survived bark harvesting and deforestation due to their growth on steep slopes. Most of the individuals in the populations of El Madrigal, Vilcabamba, Yangana, and Gonzanamá are scattered around the edges of pastures and likely subsist because of continued local medicinal use (as inferred from our occasional observations of limited bark removal). The most conserved populations were found in the private nature reserves of Angashcola and El Cristal. The four populations located along the western slope of the Eastern Cordillera Real (i.e., the western border of Podocarpus National Park) were at elevations of 2141-2271 m a.s.l. whereas the Gonzanamá and Angashcola populations were at 2643-2877 $\mathrm{m}$ a.s.1.

Samples were collected under a general permit (Contrato Marco de Acceso a Recursos Genéticos, número MAE-DNB-CM-2015-0016) issued by the Ecuadorian Ministry of the Environment. Permission to collect was granted by landowners. Individual leaves from 25 to 31 trees in each population were desiccated in plastic bags containing $10 \mathrm{~g}$ silica gel (Merck, Germany) and stored at room temperature. Total DNA was isolated from 10 to $30 \mathrm{mg}$ of dry leaf tissue using the PureLink Genomic Plant DNA Purification Kit (Invitrogen, USA) or by the CTAB method of Doyle and Doyle (1987). DNA was quantified on a NanoDrop 2000 spectrophotometer (Thermo Fisher Scientific, USA).

\section{Nuclear microsatellite marker development and screening}

Genomic DNA was isolated from a tree grown at the San Francisco Scientific Station (33 km east of Loja) using seed obtained from a tree near San Pedro de Vilcabamba. DNA was extracted from $20 \mathrm{mg}$ of dry leaf material using the protocol of Curto et al. (2013). This sample was then used for marker discovery using the Illumina MiSeq system (Illumina, USA) and primer design following the approaches described in Deck et al. (2016). This consisted of a three-primer assay using the multiplexing short tandem repeat polymorphisms with tailed primers (MSTP) method of Oetting et al. (1995) as performed by Curto et al. (2013). Fluorescently tagged M13-based primers (VIC-5'-TAATACGACTCACTATAGGG-3', PET5'-GATAACAATTTCACACAGG-3', NED-5'-TTTC CCAGTCACGACGTTG-3' or 6FAM-5'-TGTA AAACGACGGCCAGT-3') were included along with the locus-specific reverse primers (unmodified) and forward primers (modified with the appropriate M13 primer sequences as $5^{\prime}$ tails as shown in Table 1).

PCR was conducted on $10-\mu \mathrm{L}$ reactions containing 5 $\mu \mathrm{L}$ of Multiplex PCR Master Mix (Qiagen, USA), 0.4 $\mu \mathrm{L}$ of M13-tailed forward primer $(1 \mathrm{pmol} / \mu \mathrm{L}), 0.4 \mu \mathrm{L}$ of the reverse and fluorescent primers $(10 \mathrm{pmol} / \mu \mathrm{L})$, and $3.8 \mu \mathrm{L}$ of water. The reaction was promoted by the following temperature profiles: $95{ }^{\circ} \mathrm{C}$ for $15 \mathrm{~min}$; 11 cycles of denaturation at $95{ }^{\circ} \mathrm{C}$ for $30 \mathrm{~s}$, a touchdown pattern for annealing from 60 to $55{ }^{\circ} \mathrm{C}$, decreasing $0.5{ }^{\circ} \mathrm{C}$ per cycle for $60 \mathrm{~s}$, extension at $72{ }^{\circ} \mathrm{C}$ for 30 s, followed by 19 cycles of denaturation at $95{ }^{\circ} \mathrm{C}$ for 30 $\mathrm{s}$, annealing at $55{ }^{\circ} \mathrm{C}$ for $30 \mathrm{~s}$ and extension at $72{ }^{\circ} \mathrm{C}$ for $30 \mathrm{~s}$. Cycling was finished with a final extension step of $60{ }^{\circ} \mathrm{C}$ for $30 \mathrm{~min}$. All successful PCR reactions were sent for fragment analysis to the Sequencing Service at the Ludwig Maximilian University Munich. Obtained chromatograms were analyzed in Geneious using the Microsatellite plugin (Kearse et al. 2012).

\section{Microsatellite PCR and genotyping}

Two multiplex PCR reactions were performed for each sample using the three-primer method described above. Loci Coff 8 , Coff10, and Coff 20 PCR products were amplified and labeled with VIC, PET, and 6FAM, respectively, in a 10- $\mu$ L multiplex reaction containing 1× ABI Master Mix (Applied Biosystems, USA), 5-20 ng genomic DNA and the following primers: VIC-M13 $(0.4 \mu \mathrm{M})$, PET-M13 $(0.1 \mu \mathrm{M})$, 6FAM-M13 $(0.1$ $\mu \mathrm{M})$, tailed Coff 8 -F $(0.04 \mu \mathrm{M})$, tailed Coff 10-F $(0.01 \mu \mathrm{M})$, tailed Coff20-F $(0.01 \mu \mathrm{M})$, Coff8-R $(0.4 \mu \mathrm{M})$, Coff10-R (0.1 $\mu \mathrm{M})$, and Coff20-R $(0.1 \mu \mathrm{M})$. Loci Coffl 3 and Coff 15 PCR products were amplified and labeled with NED and 6-FAM, respectively, in a $10-\mu \mathrm{L}$ multiplex reaction containing $1 \times \mathrm{ABI}$ Master Mix, 5-20 ng genomic DNA and the following primers: NED-M13 $(0.1 \mu \mathrm{M}), 6$ FAM-M13 $(0.1 \mu \mathrm{M})$, tailed Coff13-F $(0.01 \mu \mathrm{M})$, tailed Coff15-F $(0.01 \mu \mathrm{M})$, Coff13-R $(0.1 \mu \mathrm{M})$, and Coff $15-\mathrm{R}(0.1 \mu \mathrm{M})$. Both multiplex reactions were run using a touchdown PCR procedure: initial denaturation at $95^{\circ} \mathrm{C}(15 \mathrm{~min}) ; 10$ cycles of $95^{\circ} \mathrm{C}(30 \mathrm{~s}), 62^{\circ} \mathrm{C}(60 \mathrm{~s})$, and $72{ }^{\circ} \mathrm{C}(30 \mathrm{~s})$ with a $1{ }^{\circ} \mathrm{C}$ reduction in annealing temperature per cycle; 20 cycles of $95^{\circ} \mathrm{C}(30 \mathrm{~s}), 52^{\circ} \mathrm{C}(30 \mathrm{~s})$, and 72 ${ }^{\circ} \mathrm{C}(30 \mathrm{~s})$; final extension at $72{ }^{\circ} \mathrm{C}(30 \mathrm{~min})$. For some samples with lower DNA concentrations, 22 cycles were performed at the $52{ }^{\circ} \mathrm{C}$ annealing temperature instead of 20 .

PCR products $(1 \mu \mathrm{L})$ were mixed with $0.15 \mu \mathrm{L}$ of GeneScan LIZ 600 size standards (Thermo Fisher Scientific) 


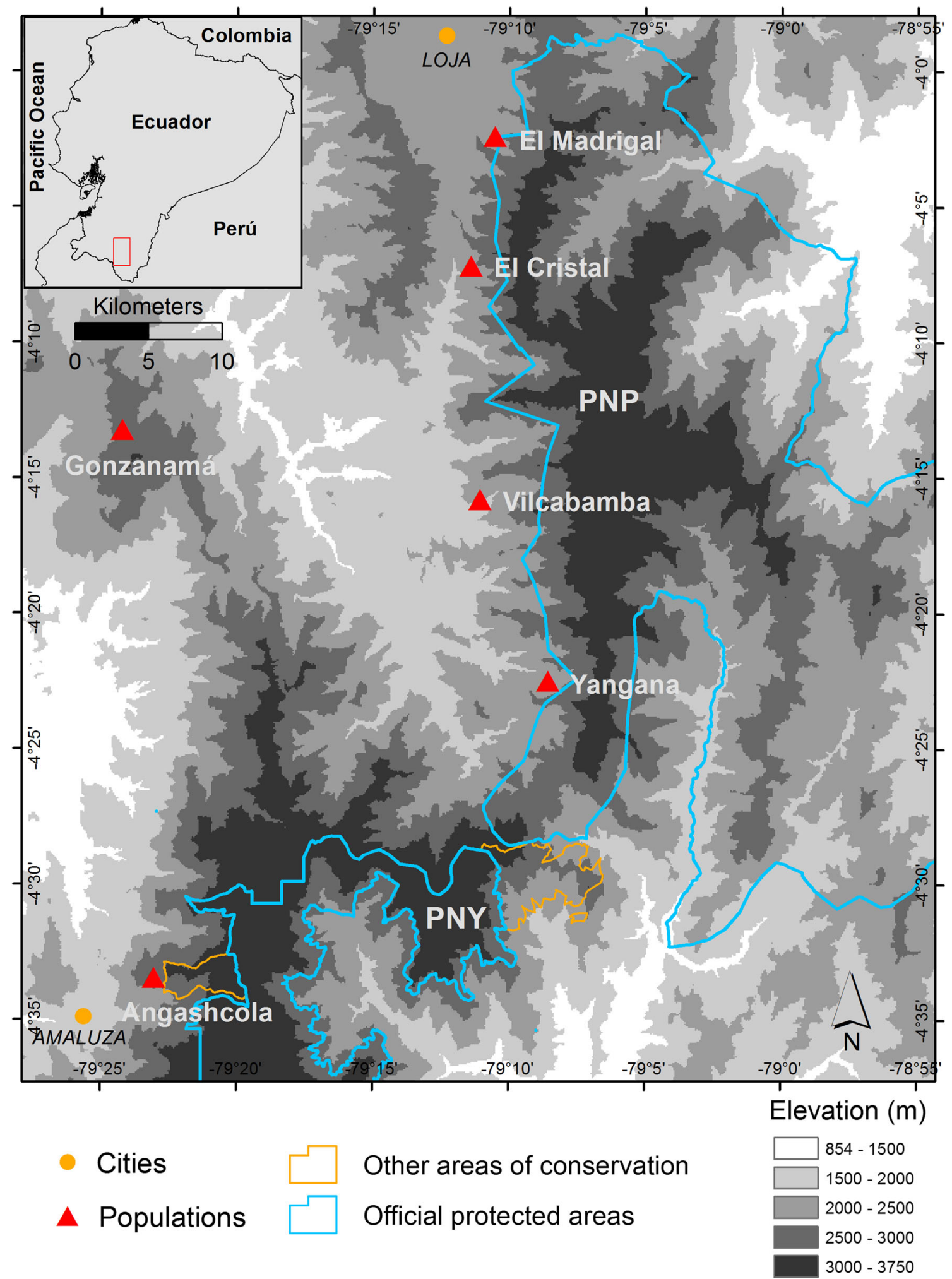

Fig. 1 Locations of sampled C. officinalis populations. PNP, Podocarpus National Park; PNY, Yacuri National Park

and $10 \mu \mathrm{L}$ of Hi-Di Formamide (Thermo Fisher Scientific). Fragments were separated on a 3500 Genetic Analyzer (Applied Biosystems) according to manufacturer's directions and scored in GeneMapper version 4.1 software (Applied Biosystems) using size bins for each locus. To avoid genotyping error when calling alleles, only peaks with amplitudes 
Table 1 Cinchona officinalis microsatellite loci descriptions

\begin{tabular}{|c|c|c|c|c|c|c|}
\hline Locus & SSR motif & $\begin{array}{l}\text { GenBank } \\
\text { accession }\end{array}$ & Primer sequences ${ }^{\mathrm{a}}$ & $\mathrm{Tm}$ & $\begin{array}{l}\text { Allele size range } \\
\text { (bp) }\end{array}$ & $A^{\mathrm{b}}$ \\
\hline Coff 8 & $(\mathrm{GA})_{3} \mathrm{G}_{2}(\mathrm{GA})_{13}$ & MH492482 & $\begin{array}{l}\text { F: 5'-TAATACGACTCACTATAGGGGGAAGGCTTCAAAC } \\
\text { AGAAATCA-3' } \\
\text { R: 5'-CTTGTCTGTTTTGTGTCAGCA-3' }\end{array}$ & $\begin{array}{l}60.6 \\
57.5\end{array}$ & 157-181 & 11 \\
\hline Coffl10 & $(\mathrm{CT})_{16}$ & MH492458 & $\begin{array}{l}\text { F: 5'-GATAACAATTTCACACAGGGAGCCGATCTTTTA } \\
\text { CCTGGGT-3' } \\
\text { R: 5'-TCAATGTTGATGGGCTTTCTCA-3' }\end{array}$ & $\begin{array}{l}61.7 \\
62.8\end{array}$ & $182-206$ & 12 \\
\hline Coffl13 & $(\mathrm{TAA})_{10}$ & MH492461 & $\begin{array}{l}\text { F: 5'-TTTCCCAGTCACGACGTTGACTGTTCACCTCTT } \\
\text { TTTGCCT-3' } \\
\text { R: 5'-GGTTGGATAGCTCCTTATCTCC-3' }\end{array}$ & $\begin{array}{l}58.0 \\
58.2\end{array}$ & $215-271$ & 19 \\
\hline Coffl15 & $(\mathrm{ACC})_{8}$ & MH492463 & $\begin{array}{l}\text { F: 5'-TGTAAAACGACGGCCAGTGAAGTGATGCCCAA } \\
\text { CAAAATTG-3' } \\
\text { R: 5'-GGGATGGGTGAGGGATTAGA-3' }\end{array}$ & $\begin{array}{l}61.7 \\
61.0\end{array}$ & $234-357$ & 16 \\
\hline Coff20 & $\begin{array}{l}(\mathrm{GGA})_{12} \mathrm{AGA} \\
\quad(\mathrm{GGA})\end{array}$ & MH492467 & $\begin{array}{l}\text { F: 5'-TGTAAAACGACGGCCAGTGCTTGTACTTGTACTGGTCC } \\
\text { A-3' } \\
\text { R: 5'-TTCCCTCCACCCTCTGAACC-3' }\end{array}$ & $\begin{array}{l}55.4 \\
63.7\end{array}$ & $175-196$ & 7 \\
\hline
\end{tabular}

a Underlined segments of the "tailed" forward primers are M13-based sequences (see text for details)

${ }^{\mathrm{b}} A=$ total number of observed alleles ( 6 populations, 162 individuals)

greater than 500 relative fluorescent units (RFU) were scored. Samples with peaks below this threshold were reamplified until reliable consensus genotypes were obtained.

\section{Statistical analysis}

Scored microsatellite genotypes were formatted in CONVERT 1.31 (Glaubitz 2004) to facilitate conversion of the data into other software formats. GENALEX 6.503 (Peakall and Smouse 2006, 2012) was used to calculate allele frequencies, observed number of alleles $(A)$, number of effective alleles $\left(A_{\mathrm{e}}\right)$, private alleles (PA), observed heterozygosity $\left(H_{\mathrm{o}}\right)$, unbiased expected heterozygosity $\left(H_{\mathrm{e}}\right)$, overall $F_{\mathrm{ST}}$ (Wright 1951, 1965), $F_{\text {ST }}$ (Meirmans 2006; Meirmans and Hedrick 2011), $G_{\text {ST }}$ (Nei 1973), $G_{\text {ST }}$ (Hedrick 2005), Jost's $\mathrm{D}_{\mathrm{EST}}$ (Jost 2008; Meirmans and Hedrick 2011), pairwise comparisons of population differentiation by $F_{\mathrm{ST}}$ and $D_{\mathrm{EST}}$, probability of identity $\left[P_{(\mathrm{ID})}\right.$ and $\left.P_{(\mathrm{ID}) \mathrm{sib}}\right]$ (Waits et al. 2001), and number of migrants per generation $\left(N_{\mathrm{m}}\right)$ based on overall $F_{\mathrm{ST}}$. The number of migrants per generation $\left(N_{\mathrm{m}}\right)$ was also calculated in GENEPOP on the Web based on the private allele method of Barton and Slatkin (1986). Exact HardyWeinberg global tests of heterozygote deficiency and inbreeding coefficients $\left(F_{\mathrm{IS}}\right)$ were calculated in GENEPOP on the Web (Raymond and Rousset 1995; Rousset 2008) and FSTAT 2.9.3.2 (Goudet 2001), respectively. The program FreeNA (Chapuis and Estoup 2007) was used to calculate null allele frequencies. Simple Mantel tests were performed using the Nei genetic pairwise distance matrix in GENALEX and the $F_{\mathrm{ST}}$ pairwise genetic differentiation matrix in $\mathrm{R}$ ( $\mathrm{R}$ Development Core Team 2004). The package hierfstat (Goudet and Jombart 2015) was used to compute the pairwise
$F_{\mathrm{ST}}$ matrix and the vegan package (Oksanen et al. 2019) to compute the Mantel test. In both cases, 9999 random permutations were performed.

BOTTLENECK v1.2.02 (Piry et al. 1999) was used to detect signs of recent bottlenecks in the studied populations based on the heterozygosity excess method (Cornuet and Luikart 1996; Luikart and Cornuet 1998). Since the Wilcoxon test gives most reliable results when less than 20 polymorphic loci are studied (Piry et al. 1999), the one-tailed Wilcoxon signed rank test was used with 10,000 iterations to test for significant excess of heterozygosity. Three mutation models were used: the infinite allele model (IAM), the stepwise mutation model (SMM), and the two-phase model (TPM). The IAM (Kimura and Crow 1964) and SMM (Ohta and Kimura 1973) are the extreme mutation models (Chakraborty and Jin 1992) while the TPM (Di Rienzo et al. 1994) is an intermediate model that more closely reflects microsatellite mutation. Since bottlenecks also cause a reduction in low frequency $(<0.1)$ alleles, the qualitative graphical method of Luikart et al. (1998), available in the BOTTLENECK software, was used to detect any mode-shift in allele frequency distributions to more intermediate frequencies. Finally, the M-ratio approach developed by Garza and Williamson (2001), which is based on the ratio of the number of microsatellite alleles to the range in allele size, was also used to detect recent bottlenecks.

Bootstrapped UPGMA dendrograms were constructed in POPTREE2 (Takezaki et al. 2010) to visualize Nei's $D_{A}$ distance (Nei et al. 1983; Takezaki and Nei 2008) with and without null allele frequency corrections calculated by FreeNA (Chapuis and Estoup 2007). Population structure was analyzed using the Bayesian model-based clustering program 
STRUCTURE 2.3.4 (Falush et al. 2003; Hubisz et al. 2009; Pritchard et al. 2000) with the admixture ancestry model. Both allele frequency models (independent and correlated) were run with length of burnin period and MCMC repetitions each set at 10,000. Running five repetitions for each potential number of clusters $(K=3-7)$, the independent allele model gave highly reproducible estimates of posterior probabilities of the data $[\operatorname{LnP}(D)]$. However, in the correlated allele model, there was significantly greater variability at some $K$ values, requiring an increase in burnin and MCMC repetition to 20,000. The plateauing nature of the correlated allele $K \mathrm{vs}$. $\mathrm{LnP}(\mathrm{D})$ graph made inference of the optimal $\mathrm{K}$ value difficult, but a $\Delta \mathrm{K}$ transformation of the data (Evanno et al. 2005) provided an estimate that was consistent with the independent allele model. Results from STRUCTURE were graphically displayed using DISTRUCT (Rosenberg 2004) and were essentially identical with either model.

Median-joining networks for chloroplast rps 16 intron sequence haplotypes were constructed in NETWORK 5.0 (Bandelt et al. 1999) using an epsilon value of 10 and weights of 10 for substitutions and 5 for indels. Manual alignments of a hypervariable $T_{n} A_{n}$ region were made in order to minimize the number of polymorphic sites.

\section{Chloroplast rps16 intron PCR and sequencing}

The rps 16 intron was initially amplified using the forward (rpS16F: 5'-AAACGATGTGGTARAAAGCAAC-3') and reverse (rpS16R: 5'-AACATCWATTGCAASGATTCGATA$3^{\prime}$ ) primers of Shaw et al. (2005). However, sequencing of a mononucleotide repeat $\left(G_{\mathrm{n}}\right)$ near the $3^{\prime}$ end of the intron gave variable results depending on which primer was used for sequencing. This problem was alleviated by designing a new reverse primer (rpS16R2: 5'-TCGGATCATAAAAA CCCACT-3') in exon 2 of rps 16 located 56-bp downstream of the original $\mathrm{rpS} 16 \mathrm{R}$ priming site. The sequence of $\mathrm{rpS} 16 \mathrm{R} 2$ was based on a Coffea arabica GenBank accession (EF044213.1).

The $20-\mu \mathrm{L}$ PCR reactions consisted of $1 \times$ GoTaq Buffer (Promega, USA), $1.5 \mathrm{mM}$ magnesium chloride (included in the buffer), $0.2 \mathrm{mM}$ each deoxyribonucleotide, $0.25 \mu \mathrm{g} / \mathrm{mL}$ bovine serum albumin, $0.5 \mu \mathrm{M}$ each of primers $\mathrm{rpS} 16 \mathrm{~F}$ and rpS16R2, 1 U GoTaq DNA Polymerase (Promega), and 2050 ng template DNA. Amplifications were carried out at $94{ }^{\circ} \mathrm{C}$ (3 min) followed by 35 cycles of $94{ }^{\circ} \mathrm{C}(30 \mathrm{~s}), 50{ }^{\circ} \mathrm{C}(45 \mathrm{~s})$, and $72{ }^{\circ} \mathrm{C}(90 \mathrm{~s})$. Final elongation was at $72{ }^{\circ} \mathrm{C}(10 \mathrm{~min})$. PCR products of approximately $940 \mathrm{bp}$ were purified with the Wizard SV Gel and PCR Clean-up System (Promega) or the Clean and Concentrator-5 Kit (Zymo, USA). Sequencing was performed by Macrogen (South Korea) or the University of Maine DNA Sequencing Facility (USA) using both PCR primers. Sequences were aligned using ClustalX2 (Larkin et al. 2007).

\section{Results}

\section{Microsatellite characteristics and discrimination power}

The Illumina MiSeq run produced 273,042 paired reads from which 271,118 passed the quality control and overlapped. Among those 20,957 contained microsatellites with flanking regions larger than $40 \mathrm{bp}$. A set of 26 primer pairs were designed from which 16 amplified in single reactions in the sample used for marker development. However, after applying them to the remaining samples, only five markers (two dinucleotide and three trinucleotide repeats) provided reliable and polymorphic PCR products, but these proved to be sufficient for our study. Repeat motifs, primers and allele summaries are shown in Table 1. Coff 13 and Coff 15 were the most polymorphic (19 and 16 total observed alleles, respectively) while Coff 20 was the least polymorphic ( 7 total alleles). Although the original sequenced alleles from Coff 13 and Coff 15 contained perfect trinucleotide repeats, the difference in sizes of observed alleles did not strictly follow a three base pair pattern.

The five-locus microsatellite analysis was successful in identifying unique genotypes in $97.5 \%$ of individuals tested (Table 2). Two consecutively sampled trees in the Vilcabamba population had identical genotypes, as did two trees in Yangana. For all populations, the mean standard probability of identity $\left[P_{(\mathrm{ID})}\right]$ was 0.00014 which is within the "reasonably low" range of 0.01-0.0001 indicated by Waits et al. (2001). The mean probability of identity among siblings $\left[P_{(\mathrm{ID}) \text { sib }}\right]$, i.e., the upper limit of probability that two individuals in a population will have the same multi-locus genotype, averaged 0.023 . Due to the high outcrossing rates of distylous species, such as $C$. officinalis, it is likely that the standard $P_{(\mathrm{ID})}$ values are more accurate estimations and that the discrimination power of the microsatellite panel was adequate for the study.

Table 2 Probability of identity and number of unique genotypes for the six C. officinalis populations using five microsatellite loci

\begin{tabular}{lllll}
\hline Population & $\mathrm{P}(\mathrm{ID})^{\mathrm{a}}$ & $\left.\mathrm{P}^{(\mathrm{IDsib})}\right)^{\mathrm{b}}$ & Number & Unique genotypes \\
\hline El Madrigal & 0.00010 & 0.021 & 26 & 26 \\
El Cristal & 0.00012 & 0.026 & 27 & 27 \\
Vilcabamba & 0.00016 & 0.024 & 25 & 23 \\
Yangana & 0.00018 & 0.028 & 26 & 24 \\
Gonzanamá & 0.00009 & 0.023 & 31 & 31 \\
Angashcola & 0.00002 & 0.014 & 27 & 27 \\
& & & 162 & 158 \\
\hline
\end{tabular}

${ }^{\mathrm{a}} \mathrm{P}(\mathrm{ID})=$ standard probability of identity

${ }^{\mathrm{b}} \mathrm{P}(\mathrm{IDsib})=$ probability of identity among siblings 


\section{Genetic diversity}

The average number of alleles per locus ranged from 5.2 to 7.6 in the six populations (Table 3 ). In the four populations having the least barriers to migration/pollination between them (El Madrigal, El Cristal, Vilcabamba and Yangana), the total number of private alleles was low (ranging from 1 to 3 ) whereas Gonzanamá and Angashcola, being more isolated, had 8 and 6 total private alleles, respectively. Observed heterozygosities $\left(H_{\mathrm{o}}\right)$ averaged over the five microsatellite loci ranged from 0.580 to 0.680 while overall expected heterozygosities $\left(H_{\mathrm{e}}\right)$ ranged from 0.616 to 0.717 (lowest in Yangana, highest

Table 3 Genetic diversity indices ${ }^{\mathrm{a}}$ for six $C$. officinalis populations at five microsatellite loci

\begin{tabular}{|c|c|c|c|c|c|c|c|c|c|c|c|c|c|c|c|c|}
\hline \multirow[b]{2}{*}{ Locus } & \multicolumn{8}{|c|}{ El Madrigal $(n=26)$} & \multicolumn{8}{|c|}{ El Cristal $(\mathrm{n}=27)$} \\
\hline & $\mathrm{H}_{\mathrm{o}}$ & $\mathrm{H}_{\mathrm{e}}$ & HW & $\mathrm{F}_{\text {IS }}$ & $\mathrm{A}$ & $\mathrm{A}_{\mathrm{e}}$ & PA & Null & $\mathrm{H}_{\mathrm{o}}$ & $\mathrm{H}_{\mathrm{e}}$ & HW & FIS & $\mathrm{A}$ & $\mathrm{A}_{\mathrm{e}}$ & $\mathrm{PA}$ & Null \\
\hline Coff 8 & 0.615 & 0.632 & ns & 0.027 & 7 & 2.6 & 0 & 0.000 & 0.593 & 0.568 & ns & -0.044 & 4 & 2.3 & 0 & 0.000 \\
\hline Coff 10 & 0.538 & 0.719 & * & 0.255 & 8 & 3.4 & 2 & 0.083 & 0.815 & 0.821 & ns & 0.008 & 6 & 5.2 & 0 & 0.000 \\
\hline Coff 13 & 0.654 & 0.690 & ns & 0.054 & 7 & 3.1 & 0 & 0.016 & 0.815 & 0.705 & ns & -0.159 & 6 & 3.2 & 1 & 0.000 \\
\hline Coff 15 & 0.731 & 0.758 & * & 0.037 & 6 & 3.9 & 0 & 0.055 & 0.704 & 0.772 & ns & 0.090 & 10 & 4.1 & 1 & 0.001 \\
\hline Coff 20 & 0.731 & 0.546 & ns & -0.348 & 3 & 2.2 & 0 & 0.000 & 0.259 & 0.234 & ns & -0.110 & 3 & 1.3 & 0 & 0.000 \\
\hline Overall & 0.654 & 0.669 & * & 0.023 & 6.2 & 3.0 & 2 & 0.031 & 0.637 & 0.620 & ns & -0.028 & 5.8 & 3.2 & 2 & 0.000 \\
\hline
\end{tabular}

\begin{tabular}{|c|c|c|c|c|c|c|c|c|c|c|c|c|c|c|c|c|}
\hline \multirow[b]{2}{*}{ Locus } & \multicolumn{8}{|c|}{ Vilcabamba $(\mathrm{n}=25)$} & \multicolumn{8}{|c|}{ Yangana $(n=26)$} \\
\hline & $\mathrm{H}_{\mathrm{o}}$ & $\mathrm{H}_{\mathrm{e}}$ & HW & FIS & A & $\mathrm{A}_{\mathrm{e}}$ & $\mathrm{PA}$ & Null & $\mathrm{H}_{\mathrm{o}}$ & $\mathrm{H}_{\mathrm{e}}$ & $\mathrm{HW}$ & $\mathrm{F}_{\text {IS }}$ & A & $\mathrm{A}_{\mathrm{e}}$ & PA & Null \\
\hline Coff 8 & 0.480 & 0.662 & ns & 0.279 & 5 & 2.8 & 0 & 0.073 & 0.269 & 0.313 & ns & 0.142 & 5 & 1.4 & 1 & 0.053 \\
\hline Coff 10 & 0.880 & 0.763 & ns & -0.157 & 6 & 4.0 & 0 & 0.000 & 0.846 & 0.831 & ns & -0.019 & 7 & 5.4 & 1 & 0.000 \\
\hline Coff 13 & 0.800 & 0.710 & ns & -0.129 & 6 & 3.3 & 1 & 0.000 & 0.654 & 0.652 & ns & -0.002 & 6 & 2.8 & 0 & 0.005 \\
\hline Coff 15 & 0.720 & 0.687 & ns & -0.049 & 6 & 3.1 & 0 & 0.000 & 0.615 & 0.735 & $* *$ & 0.165 & 7 & 3.6 & 1 & 0.076 \\
\hline Coff 20 & 0.520 & 0.422 & ns & -0.238 & 3 & 1.7 & 0 & 0.000 & 0.692 & 0.548 & ns & -0.269 & 3 & 2.2 & 0 & 0.000 \\
\hline Overall & 0.680 & 0.649 & ns & -0.049 & 5.2 & 3.0 & 1 & 0.015 & 0.615 & 0.616 & ns & 0.001 & 5.6 & 3.1 & 3 & $\mathbf{0 . 0 2 7}$ \\
\hline
\end{tabular}

\begin{tabular}{|c|c|c|c|c|c|c|c|c|c|c|c|c|c|c|c|c|}
\hline \multirow[b]{2}{*}{ Locus } & \multicolumn{8}{|c|}{ Gonzanama $(\mathrm{n}=31)$} & \multicolumn{8}{|c|}{ Angashcola $(n=27)$} \\
\hline & $\mathrm{H}_{\mathrm{o}}$ & $\mathrm{H}_{\mathrm{e}}$ & HW & $\mathrm{F}_{\mathrm{IS}}$ & $\mathrm{A}$ & $\overline{A_{e}}$ & PA & Null & $\mathrm{H}_{\mathrm{o}}$ & $\overline{\mathrm{H}_{\mathrm{e}}}$ & HW & $\mathrm{F}_{\mathrm{IS}}$ & $\mathrm{A}$ & $\overline{A_{e}}$ & $\mathrm{PA}$ & Null \\
\hline Coff 8 & 0.645 & 0.665 & ns & 0.030 & 4 & 2.9 & 0 & 0.000 & 0.778 & 0.822 & ns & 0.055 & 9 & 5.2 & 1 & 0.000 \\
\hline Coff 10 & 0.419 & 0.497 & ns & 0.158 & 4 & 2.0 & 0 & 0.037 & 0.741 & 0.685 & ns & -0.083 & 8 & 3.1 & 0 & 0.000 \\
\hline Coff 13 & 0.677 & 0.774 & ns & 0.126 & 9 & 4.2 & 2 & 0.025 & 0.630 & 0.808 & $\star \star * *$ & 0.224 & 9 & 4.8 & 3 & 0.123 \\
\hline Coff 15 & 0.645 & 0.810 & ** & 0.206 & 12 & 4.9 & 5 & 0.090 & 0.444 & 0.747 & ** & 0.410 & 6 & 3.7 & 0 & 0.162 \\
\hline Coff 20 & 0.516 & 0.493 & ns & -0.047 & 5 & 1.9 & 1 & 0.000 & 0.593 & 0.524 & ns & -0.134 & 6 & 2.1 & 2 & 0.000 \\
\hline Overall & 0.580 & 0.648 & * & 0.105 & 6.8 & 3.2 & 8 & 0.030 & 0.637 & 0.717 & $\star \star \star *$ & 0.114 & 7.6 & 3.8 & 6 & 0.057 \\
\hline
\end{tabular}

ns $=$ not significant

$* P=0.05 ; * * P=0.01 ; * * * P=0.001$

${ }^{\text {a }}$ Observed heterozygosity $\left(H_{\mathrm{o}}\right)$, unbiased expected heterozygosity $\left(H_{\mathrm{e}}\right)$, exact test of heterozygosity deficiency $(\mathrm{HW})$, inbreeding coefficient $\left(F_{\mathrm{IS}}\right)$, number of observed alleles $(A)$, number of effective alleles $\left(A_{\mathrm{e}}\right)$, number of private alleles (PA), estimate of null allele frequency (null). Overall values are averages for $H_{\mathrm{o}}, H_{\mathrm{e}}, A, A_{\mathrm{e}}$, and null; total for PA; global for $F_{\mathrm{IS}}$ 
in Angashcola). The number of effective alleles $\left(A_{\mathrm{e}}\right)$ was highest in Angashcola (3.8 vs. 3.0-3.2 for the other populations), consistent with its greater expected heterozygosity and average number of alleles.

Three populations (E1 Madrigal, Gonzanamá, and Angashcola) showed significant deviation from HardyWeinberg equilibrium (heterozygote deficiency) over all loci, but only Gonzanamá and Angashcola had relatively high positive inbreeding coefficients (global $F_{I S}$ values $>0.10$ ). Locus Coff 15 showed the highest estimated null allele frequency across all populations (average of 0.064 ), especially in the Gonzanamá and Angashcola populations (0.090 and 0.162, respectively). Angashcola also had a relatively high estimated null allele frequency $(0.123)$ at the Coff 13 locus. The appearance of null alleles would be more likely in these two populations which are the most isolated from the source of genomic DNA (near Vilcabamba) that was used for microsatellite screening (Chapuis and Estoup 2007). Therefore, HardyWeinberg disequilibrium in Angashcola, and possibly Gonzanamá, could be attributed to the presence of null alleles rather than to factors such as inbreeding or departure from random mating.

The number of migrants per generation $\left(N_{\mathrm{m}}\right)$ across all loci was estimated to be 1.2 ( $F_{\mathrm{ST}}$ method) or 1.4 (private allele method), indicating that there is adequate gene flow between populations to counter the negative effect of genetic drift on heterozygosity (Nason and Hamrick 1997). Bottleneck analysis of the data yielded no convincing evidence of recent bottlenecks (Supplementary Table S1). Of the three mutation models, the only significant result for heterozygosity excess was for the Vilcabamba population using the IAM which is the least conservative model and more prone to type I errors (Cornuet and Luikart 1996). All M ratios were above 1.7, well above the critical value of 0.68 (Garza and Williamson 2001). Similarly, there were no significant mode shifts in the allele frequency distribution histograms that would be indicative of low-frequency allele loss caused by bottlenecks.

\section{Population structure}

Wright's $F_{\mathrm{ST}}$ (Wright 1951, 1965) is a traditional measure of subpopulation genetic differentiation, but its current utility has been questioned because its maximum value, i.e., complete differentiation, can be severely reduced from 1 when using highly polymorphic markers such as microsatellites (Neigel 2002; Jost 2008; Meirmans and Hedrick 2011). The overall $F_{\mathrm{ST}}$ calculated from our microsatellite data is 0.180 , and the related $G_{\mathrm{ST}}($ Nei 1973) value is similar (0.166). Standardization of these values to a scale of $0-1$ by dividing by their maximum values yields the more insightful measures of $F^{\prime}{ }_{\mathrm{ST}}$ (Meirmans 2006) and $G_{\text {ST }}$ (Hedrick 2005). For the C. officinalis populations, $F^{\prime}{ }_{\mathrm{ST}}=0.561$ and $\mathrm{G}_{\mathrm{ST}}{ }_{\mathrm{ST}}=0.542$, values which imply a higher level of subpopulation differentiation. Jost's $D$, which is claimed to be a much more reliable standardized measure of differentiation (Jost 2008), was slightly lower $\left(D_{\mathrm{EST}}=0.451\right)$ although still an indication of relatively high subpopulation differentiation. The above values were derived from data without null allele correction, but overall $F_{\mathrm{ST}}$ decreased by only $1.9 \%$ when the null allele correction was applied using FreeNA.

Pairwise comparisons of population differentiation were calculated for both $F_{\mathrm{ST}}$ and Jost's $D_{\mathrm{EST}}$ (Table 4). Pairwise $F_{\mathrm{ST}}$ values ranged from 0.064 to 0.168 while Jost's $D_{\text {EST }}$ ranged from 0.220 to 0.763 . The only relative difference was that the El Madrigal population was slightly less differentiated from Angashcola (0.130) than Gonzanamá $(0.141)$ in the $F_{\mathrm{ST}}$ comparison but slightly more differentiated from Angashcola (0.619) than Gonzanamá (0.587) in the Jost's $D_{\text {EST }}$ comparison. The latter comparison is more geographically consistent. In both comparisons, the El Madrigal population is more genetically similar to the Vilcabamba population than to its neighboring El Cristal population. The Jost's $D_{\text {EST }}$ comparison, in particular, shows a high degree of differentiation (0.619-0.763) between the four populations on the western slope of the Eastern Cordillera Real and the Angashcola

Table 4 Pairwise population $F_{\mathrm{ST}}$ (below diagonal) and Jost's $D_{\mathrm{EST}}$ (above diagonal) comparisons.

\begin{tabular}{|c|c|c|c|c|c|c|}
\hline & El Madrigal & El Cristal & Vilcabamba & Yangana & Gonzanamá & Angashcola \\
\hline El Madrigal & 0.000 & 0.340 & 0.220 & 0.377 & 0.587 & 0.619 \\
\hline El Cristal & 0.095 & 0.000 & 0.193 & 0.376 & 0.411 & 0.763 \\
\hline Vilcabamba & 0.064 & 0.062 & 0.000 & 0.228 & 0.400 & 0.667 \\
\hline Yangana & 0.105 & 0.113 & 0.072 & 0.000 & 0.442 & 0.701 \\
\hline Gonzanamá & 0.141 & 0.115 & 0.107 & 0.123 & 0.000 & 0.548 \\
\hline Angashcola & 0.130 & 0.168 & 0.144 & 0.159 & 0.122 & 0.000 \\
\hline
\end{tabular}

Results were significant at $P=0.001$ for all values (999 permutations) 

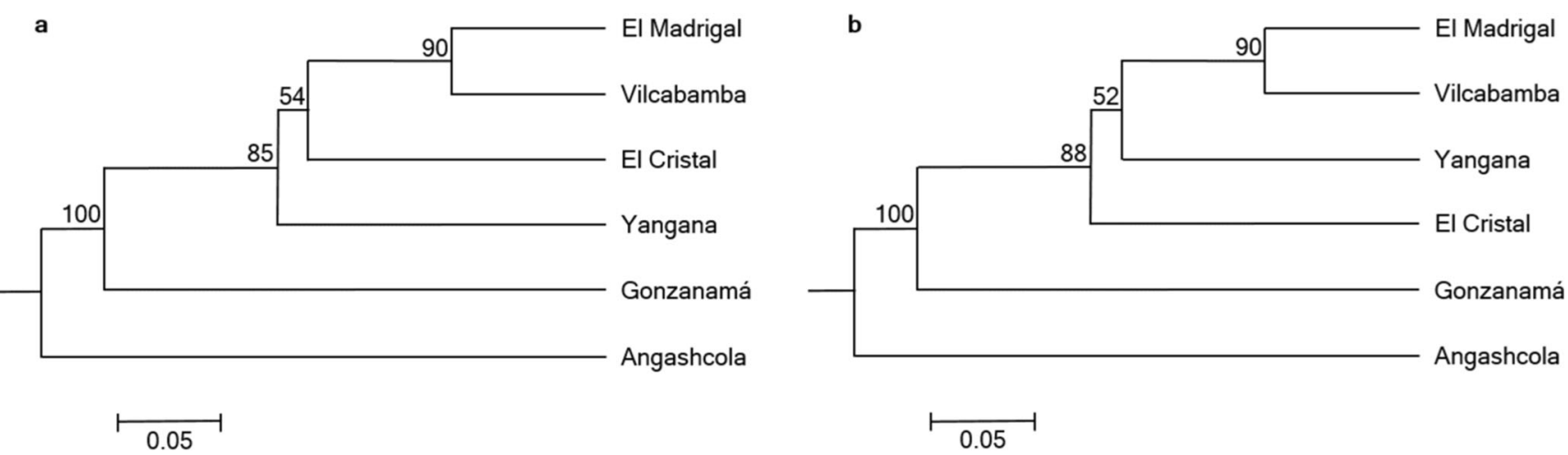

Fig. 2 UPGMA dendrograms of $C$. officinalis microsatellite data. a Without null allele correction; $\mathbf{b}$ with null allele correction. Bootstrap percentages (1000 replications) are at nodes

population. As with overall $F_{\mathrm{ST}}$, correction for null allele frequencies decreases the average pairwise $F_{\mathrm{ST}}$ only slightly (2.0\%).

Because of the possibility of null alleles, distance trees were constructed from microsatellite data with and without null allele frequency corrections (Fig. 2). In both cases, the group containing the populations located on the western slope of the Eastern Cordillera Real (El Madrigal, El Cristal, Vilcabamba, and Yangana) was well supported with high bootstrap values although the positions of El Cristal and Yangana were reversed and not well supported. The sister group of El Madrigal and Vilcabamba appeared in both dendrograms. The positions of Gonzanamá and Angashcola were unaffected by the null allele corrections. Using data without null allele correction (Fig. 2a) gave a slightly more geographically consistent dendrogram.

The program STRUCTURE was used to assess the microsatellite data by a Bayesian clustering approach (Fig. 3). Although six nominal populations were sampled, the inferred cluster size $(K)$ was determined to be five by either the independent or correlated alleles model with the admixture patterns essentially the same between models. The majority of individuals in the El Cristal, Yangana, Gonzanamá, and Angashcola populations had ancestry within their unique clusters, but the fifth cluster was composed mainly of individuals from El Madrigal and Vilcabamba with significant admixture from the Yangana cluster and, to a lesser extent, El Cristal. Very little admixture from the Gonzanamá cluster appeared in El Madrigal, El Cristal and Vilcabamba, and essentially no admixture from the Angashcola cluster was found in any population except for a few individuals in Gonzanamá. The least admixture was seen in the more isolated Angashcola population. Although geographically located between the El Madrigal and Vilcabamba populations, El Cristal shows a different genetic background. The STRUCTURE results are consistent with the distance tree analysis (Fig. 2).

Using the Mantel test, correlation between the Nei genetic distance and geographic distances of population pairs was not significant $(r=0.045, p=0.181)$. With the $F_{\mathrm{ST}}$ genetic distance, the $r$ value was slightly higher but only weakly significant $(r=0.102, p=0.049)$.

\section{Chloroplast haplotype variation and distribution}

Six haplotypes were detected at the chloroplast rps 16 intron (Table 5). The four polymorphic sites included one base substitution and three repetitive regions. Haplotype A, the presumptive ancestral sequence, was by far the most abundant with an overall frequency of 0.877 . Haplotypes D and E, with frequencies of 0.006 , were found in only one individual each.

Haplotype distributions are shown in Fig. 4. El Madrigal had the most haplotype diversity with five sequence variants (A-E). However, the populations of El Cristal, Vilcabamba, Yangana, and Gonzanamá were fixed at haplotype A. The latter three populations occur in the most degraded habitat and are the smallest (less than 50 individuals), suggesting that fixation may have occurred in this haploid genome through genetic drift. Angashcola was the only population containing

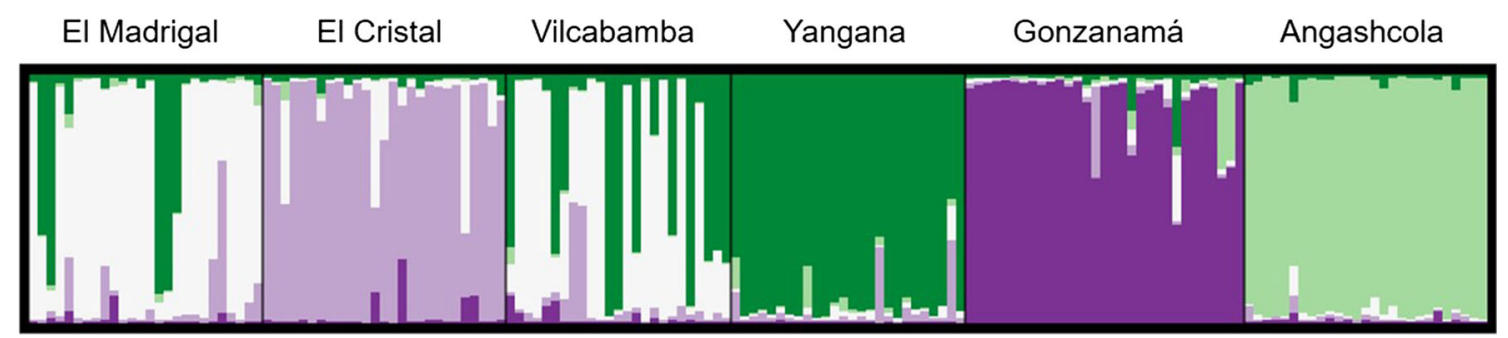

Fig. 3 Bayesian cluster analysis of $C$. officinalis microsatellite data from STRUCTURE $(K=5)$ 
Table 5 Chloroplast haplotype sequence variation in the rps 16 intron based on a $781 \mathrm{bp}$ alignment

\begin{tabular}{llllll}
\hline & \multicolumn{3}{l}{ Polymorphic sites $^{\mathrm{a}}$} & \multicolumn{2}{c}{ GenBank accession } \\
\cline { 2 - 5 } Haplotype & 39 & $467-$ & $579-$ & $603-$ & \\
& & 480 & 588 & 610 & \\
\hline $\mathrm{A}$ & $\mathrm{G}$ & $\mathrm{T}_{9} \mathrm{~A}_{4}-$ & $\mathrm{T}_{9}-$ & $\mathrm{A}_{7}-$ & MK071268 \\
B & $\mathrm{G}$ & $\mathrm{T}_{10} \mathrm{~A}_{4}$ & $\mathrm{~T}_{9}-$ & $\mathrm{A}_{7}-$ & MK071269 \\
$\mathrm{C}$ & $\mathrm{G}$ & $\mathrm{T}_{9} \mathrm{~A}_{4}-$ & $\mathrm{T}_{10}$ & $\mathrm{~A}_{7}-$ & MK071270 \\
D & $\mathrm{G}$ & $\mathrm{T}_{7} \mathrm{~A}_{6}-$ & $\mathrm{T}_{8}--$ & $\mathrm{A}_{7}-$ & MK071271 \\
E & $\mathrm{C}$ & $\mathrm{T}_{9} \mathrm{~A}_{4}-$ & $\mathrm{T}_{10}$ & $\mathrm{~A}_{7}-$ & MK071272 \\
F & $\mathrm{G}$ & $\mathrm{T}_{10} \mathrm{~A}_{3}-$ & $\mathrm{T}_{9}-$ & $\mathrm{A}_{8}$ & MK071273 \\
\hline
\end{tabular}

${ }^{\mathrm{a}}$ Dash $=$ deletion

haplotype $\mathrm{F}$ and the only one where haplotype A was the least abundant. The latter observation is consistent with the previous analyses which showed a greater genetic divergence of Angashcola relative to the other populations.

The construction of a unique median-joining network of haplotypes was not possible owing to the hypervariability of the second polymorphic site (see Table 5) which allowed a number of possible alignments and networks (not shown). However, all networks placed haplotype $\mathrm{A}$ as the ancestral sequence. Depending on the alignment used, haplotype $\mathrm{F}$ (unique to Angashcola) was either directly derived from haplotype A, indirectly derived from haplotype A via haplotype $\mathrm{B}$, or it shared a common (undetected) ancestral haplotype with haplotype $\mathrm{B}$.

\section{Discussion}

Habitat fragmentation can have potentially serious genetic consequences, including reduction in genetic diversity and gene flow, higher rates of inbreeding and greater interpopulation divergence due to genetic drift (Lowe et al. 2005). Some tropical forest plants are particularly susceptible to the effects of habitat fragmentation and degradation owing to their reliance on animal pollinators, complex selfincompatibility mechanisms, and high rates of outcrossing (Hamrick and Murawski 1990). In a meta-analysis of more than 100 plant studies, Aguilar et al. (2008) generally found significant negative effects of habitat fragmentation on expected heterozygosity, allele number, percent polymorphic loci, and outcrossing rates whereas increased inbreeding was less common. In addition, the analysis showed that loss of heterozygosity was greater when more time had passed since fragmentation.

Since there are no known remaining extended forests of C. officinalis, it is impossible to determine with certainty whether the moderately high heterozygosity of the six fragmented populations (average $H_{\mathrm{e}}=0.653$ ) in our study reflects that of the original forest, or if there has been an actual reduction in heterozygosity over nearly 400 years of harvesting this species. However, compared to Angashcola, the largest and least impacted population in this study, the other five populations had expected heterozygosities that were $11 \%$ lower on average. Mean allelic richness and number of effective alleles for these five populations were $22 \%$ and $18 \%$ lower than Angashcola, respectively. Assuming that the Angashcola population analysis provides a minimum estimation of the original forest's genetic diversity, these data support the conclusions of Vranckx et al. (2012) that fragmentation may only have a slight negative impact on heterozygosity, but allelic richness is lost at a higher rate. Also, for microsatellites, changes in allelic diversity are considered to be more informative than heterozygosity for assessing genetic erosion (Kang et al. 2008; Spencer et al. 2000).

Loss of genetic diversity through genetic drift cannot be completely discounted in $C$. officinalis populations, but, according to Young et al. (1996), our estimation of gene flow from microsatellite data $\left(N_{\mathrm{m}}=1.2-1.4\right)$ appears to be high enough to counter genetic erosion in the nuclear genome caused by drift. Gene flow via long-distance pollination and seed dispersal are mechanisms by which fragmented forest populations can maintain genetic diversity (Kramer et al. 2008), and even isolated trees can act as "stepping stones" between fragmented populations (Lander et al. 2010; Lowe et al. 2005). Seed dispersal is an unlikely agent of gene flow between fragmented $C$. officinalis populations because the winged seeds of Cinchona species are probably incapable of dispersal over such long distances. According to Vittoz and Engler (2007), winged seeds in forest species can reach a dispersion distance of only $40-150 \mathrm{~m}$. Due to their purplepink coloration and tubular shape, the flowers of $C$. officinalis are mainly pollinated by hummingbirds (Altshuler 2003; Sazima et al. 1996; Tropicos 2018) which are capable of foraging over long distances (Murcia 1996) although they typically forage within a narrow home territory (Renner 1998). Some hummingbirds can persist in a matrix of forest fragments and cattle pasture (Stouffer and Bierregaard Jr 1995), but other studies have shown that open areas severely reduce their visitations to fragments (Lindberg and Olesen 2001; Magrach et al. 2012). Whether the large blocks of open pasture separating fragments of $C$. officinalis are impediments to hummingbird pollination is likely species-dependent and remains unstudied.

Two populations in this study, Gonzanamá and Angashcola, had relatively high $F_{\text {IS }}$ values $(0.105$ and 0.114 , respectively). We are hesitant to conclude that inbreeding is the cause. Instead, heterozygote deficiency is more likely explained by the presence of null alleles, especially in locus Coff 15 which deviated significantly from Hardy-Weinberg equilibrium in four of the six populations. In fact, of all the populations, inbreeding would be least expected in 


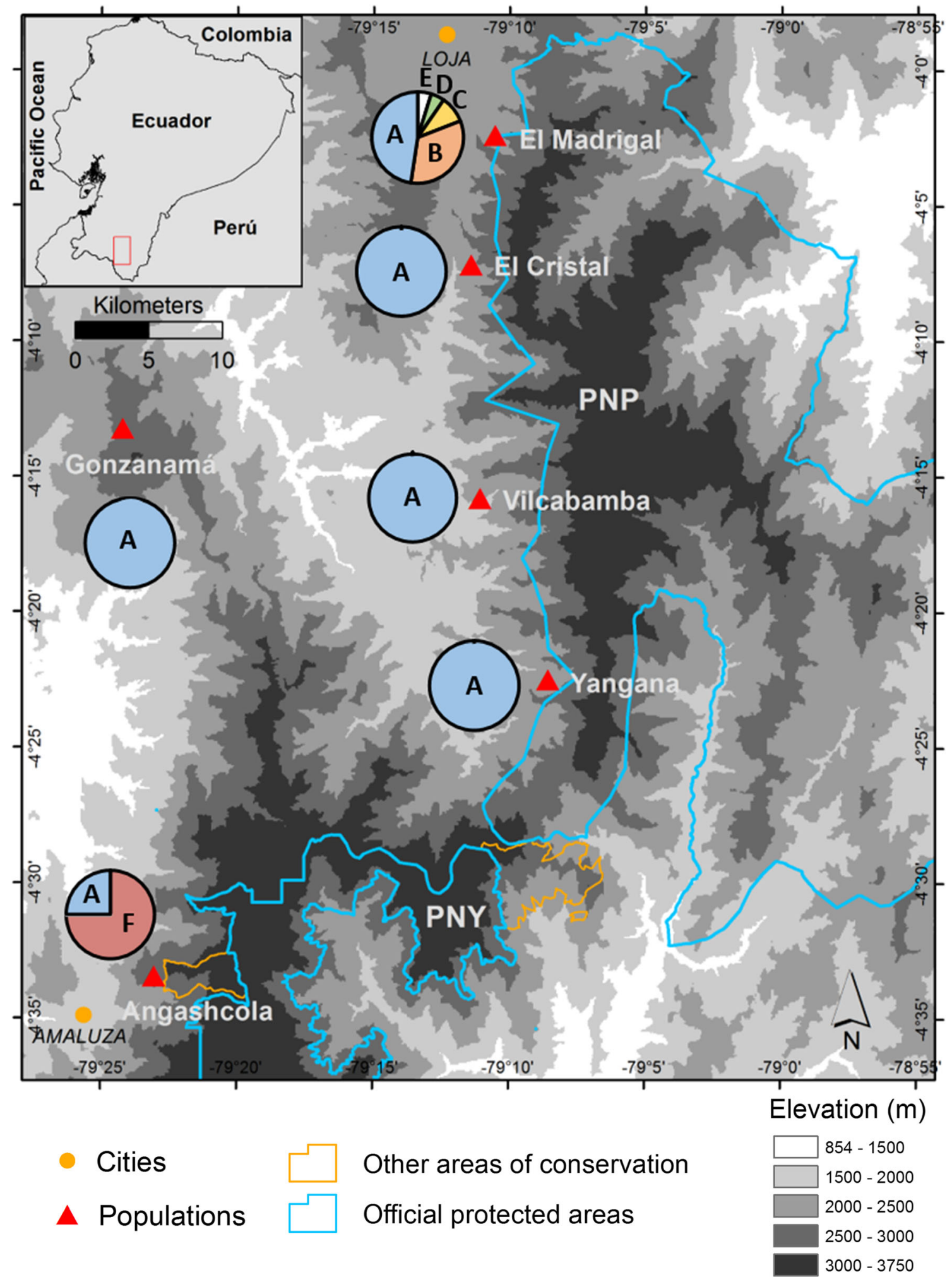

Fig. 4 Chloroplast rps 16 intron haplotype frequency distributions of C. officinalis populations. PNP, Podocarpus National Park; PNY, Yacuri National Park

Angashcola since it has the highest number of individuals. There would, however, be a higher probability of null alleles in Angashcola because of its greater divergence from the population used to construct the microsatellite library (Chapuis and Estoup 2007). Although the presence of null alleles can inflate $F_{\mathrm{ST}}$ values and genetic distances in 
significantly differentiated populations (Chapuis and Estoup 2007), the difference between corrected and uncorrected overall $F_{\mathrm{ST}}$ or average pairwise $F_{\mathrm{ST}}$ values in our study was marginal $(\leq 2 \%)$.

Many studies have shown that after forest fragmentation, first generation progeny (seedlings and saplings) have reduced genetic diversity and sometimes show signs of reduced fitness (Cascante et al. 2002; Fernández-M and Sork 2007; Lowe et al. 2005; Nason and Hamrick 1997). Therefore, Lowe et al. (2015) have suggested that future studies be focused on the progeny of forest fragments. Such reductions in fitness could be due to environmental changes in the modified habitats as well as genetic factors (Cascante et al. 2002). Limited studies have not shown evidence of reduced fitness of C. officinalis seeds under controlled germination conditions: $70 \%$ germination with light exposure (Romero-Saritama and Munt 2017), 87\% with hydrogen peroxide and light exposure (Armijos-González and Pérez-Ruiz 2016), and 71-83\% in sand and peat (Guáman et al. 2017). However, according to Acosta (1947), germination of older seeds is greatly reduced. Further research is needed to determine whether postfragmentation progeny of $C$. officinalis are indeed suffering from genetic erosion and reduced fitness.

The overall genetic differentiation of the $C$. officinalis populations is relatively high as measured by $F_{\mathrm{ST}}, G_{\mathrm{ST}}$, and Jost's $D_{\mathrm{EST}}$, although the higher value of $D_{\mathrm{EST}}$ is likely more dependable since $G_{\mathrm{ST}}$ (and $F_{\mathrm{ST}}$ ) typically underestimates differentiation when heterozygosity is high and $\mathrm{N}_{\mathrm{m}}>1$ (Leng and Zhang 2011). In a simulated study using microsatellite data under the finite island model, Leng and Zhang (2011) suggested that one explanation for higher values $(>0.15)$ of $G_{\mathrm{ST}}$ and $D$ is small effective population size $(<100)$. Pairwise population comparisons, especially with Jost's $D_{\mathrm{EST}}$, showed moderate genetic differentiation among the four populations located on the western slope of the Eastern Cordillera Real, but greater differentiation was seen between those populations and the other two (Gonzanamá and Angashcola) where mountainous terrain up to $3000 \mathrm{~m}$ or more would preclude easy gene flow. Angashcola, in particular, was highly differentiated from the Eastern Cordillera Real populations owing to its remote location. This finding supports our original hypothesis that the complex geological history of southern Ecuador would encourage divergence of some populations.

Distance-based tree analysis yielded similar results. The only geographically inconsistent placement in the UPGMA dendrogram was the El Cristal population which did not group between its neighboring populations (El Madrigal and Vilcabamba). Upon further investigation, we discovered that this population had not been cut over the past 100 years (G. Samaniego, personal communication). Review of the microsatellite data revealed that El Cristal had approximately twice the percentage of rare alleles (frequency $<0.05$ ) compared to the average of the neighboring populations which is consistent with less historical cutting. Bayesian cluster analysis gave similar results in that it separated El Cristal from the El Madrigal-Vilcabamba cluster although there was some admixture. El Cristal is located in the region of Cajanuma, an area in which a royal decree in 1782 prohibited harvesting due to overexploitation of the tree (Arias 2017). However, there is no subsequent documentation regarding unique management approaches in Cajanuma that might have influenced the species' genetic composition. Regardless of the reasons for this slight phylogeographic discrepancy, the Eastern Cordillera Real populations appear to share a recent common ancestry and were probably part of a continuous population prior to deforestation.

Since haploid genomes have smaller effective population sizes than diploid genomes (Weising et al. 2005), chloroplast loci are more sensitive to genetic drift than nuclear markers (Provan et al. 2001). Haplotype A of the C. officinalis chloroplast rps 16 intron, the most common and widespread variant, is presumably the ancestral form based on its abundance and centrality in median-joining networks. Although there was no evidence of genetic bottlenecks from the microsatellite data, fixation of haplotype A by genetic drift occurred in four out of six of the $C$. officinalis populations. Despite the four rare haplotypes (B-E) found at El Madrigal, haplotype A was still the most abundant in that population. However, haplotype $\mathrm{F}$ was the most frequent in, and unique to, Angashcola. As with the microsatellite data, the chloroplast analysis underscores the divergent nature of the Angashcola population relative to the others.

Both orogeny and glacial cycles undoubtedly played a role in the phylogeographic history of C. officinalis. According to Gentry (1982), much of the diversity of the Neotropics can be attributed to rapid species diversification caused by recent Andean orogeny $(<10 \mathrm{MY})$. The complex mountain terrain of southern Ecuador combined with climatic fluctuations during glacial-interglacial periods created barriers to migration that would have led to isolation and species divergence (Beck and Richter 2008; Jørgensen et al. 1995). In fact, this general area of southern Ecuador is thought to be the center of diversity for the genus Cinchona (Andersson 1998).

The greater genetic differentiation of the Angashcola population of $C$. officinalis implies that there was an ancient split of an ancestral population, although the timing of its divergence (i.e., Pleistocene or late Miocene) remains unknown. The Gonzanamá population has genetic characteristics that are intermediate between Angashcola and the Eastern Cordillera Real populations and may provide a clue as to the general location of the split. In addition to the mountain barrier $(>3000 \mathrm{~m}$ ) separating the Eastern Cordillera Real from Angashcola, the large valley east of Gonzanamá has also been an effective interglacial barrier to migration of $C$. officinalis. A northwestsoutheast migration route along the mountain slopes 
between Gonzanamá and Yangana is possible. The more related populations on the western slope of the Eastern Cordillera Real exist in a relatively narrow elevational range of roughly $2100-2300 \mathrm{~m}$. Much of the more accessible land below that elevation has been cleared for pasture while growth above that range is limited by an abrupt climatic transition which favors páramo. Both the Gonzanamá and Angashcola populations, however, have adapted to higher elevations (approximately 2600-2800 $\mathrm{m}$ ) in inter-Andean mountain ranges further west. This upward migration is likely due to warmer, less windy conditions away from the Amazonian fronts that cross the eastern cordillera. Mantel tests using Nei's distance and $F_{\mathrm{ST}}$ did not show strong evidence of isolation by distance as the $r$ values were low and only one of the tests $\left(F_{\mathrm{ST}}\right)$ was weakly significant. In a review of the Mantel test, Guillot and Rousset (2013) referenced a number of studies that expressed concern about the test's type I error rate, so we have little confidence in the marginal significance ( $p=0.049$ ) of the test using $F_{\mathrm{ST}}$ data.

In addition to the historic harvesting of $C$. officinalis for its medicinal value, its habitat has also been severely degraded by deforestation and conversion to pasture or pineeucalyptus plantations (Tapia-Armijos et al. 2015). However, despite the obvious decrease in population size and continuing threats to the remaining habitat, the conservation status of this species has yet to be assessed by the IUCN (2018).

In our study, all six fragmented populations of $C$. officinalis in Loja province were found to have moderate levels of genetic diversity. However, the more remote population of Angashcola has the highest genetic diversity, is genetically unique as measured by nuclear microsatellite and chloroplast analysis, and should therefore be given highest conservation priority. Fortunately, of all the populations studied, Angashcola has the largest number of individuals, the most intact habitat, and is managed as a private reserve. The El Madrigal and El Cristal C. officinalis populations are also located in private reserves and therefore will have the opportunity to recover. However, the populations of Gonzanamá, Yangana, and Vilcabamba are very small and located on highly degraded agricultural land. Without intervention, these populations are in danger of extirpation.

Remaining fragments of $C$. officinalis in southern Ecuador and northern Peru should be identified and studied in order to better understand the conservation needs of this species. Isolated individuals scattered at the peripheries of pastures or at higher elevations need to be evaluated for their value in maintaining gene flow between populations. In fact, in recent expeditions (Arias 2017), individuals or small groups of trees have been found on the western slope of the Eastern Cordillera Real between some of the populations assessed in our study. Characterization of plant-pollinator interactions should be performed in order to develop strategies (Menz et al. 2011) to reconnect $C$. officinalis fragments with native pollinators. Additionally, studies must be designed to detect and understand any reductions of natural regeneration or fitness. Finally, efforts to educate the local population and landowners on the importance of conserving the few remaining populations of this threatened species should continue.

Data archiving statement The microsatellite dataset from the current study is available from the corresponding author upon request. GenBank accession numbers for nuclear microsatellite loci sequences and chloroplast haplotype sequences are provided in Tables 1 and 4, respectively.

Acknowledgments The authors express their gratitude to Dr. Gustavo Samaniego, owner of Finca El Cristal, to Hugo Tapia, co-owner of Reserva El Madrigal, and to the Comuna Cochecorral, especially Sr. Adán Gonzaga, administrators of Reserva Comunal Bosque de Angashcola for access to their $C$. officinalis populations. We also thank María Fernanda Tapia for her assistance in creating the map shown in this work, Carlos Manchego for collecting the leaf material used to develop the microsatellites, and Itziar Arnelas and Tim Breton for reading early versions of the manuscript. Chris Brinegar wishes to thank the Secretaría de Educación Superior, Ciencia, Technología e Innovación (SENESCYT) of the government of Ecuador, the Fulbright Commissions of the United States and Ecuador, and Bonnie Brinegar for their financial support and also the University of Maine DNA Sequencing Facility.

Authors' contributions Augusta Cueva-Agila conceived the study. Samples were collected by Diego Vélez-Mora., Augusta Cueva-Agila, and Chris Brinegar. DNA isolation, PCR, and genotyping were conducted by Daniela Arias and Chris Brinegar. Microsatellite characterizations were performed by Manuel Curto and Harald Meimberg. Data were analyzed by Chris Brinegar and Augusta Cueva-Agila. The manuscript was written by Chris Brinegar, Augusta Cueva-Agila, Diego Vélez-Mora, and Manuel Curto. All authors have reviewed the final version of the manuscript.

\section{Compliance with ethical standards}

Conflict of interest The authors declare that they have no conflict of interest.

Open Access This article is distributed under the terms of the Creative Commons Attribution 4.0 International License (http:// creativecommons.org/licenses/by/4.0/), which permits unrestricted use, distribution, and reproduction in any medium, provided you give appropriate credit to the original author(s) and the source, provide a link to the Creative Commons license, and indicate if changes were made.

\section{References}

Acosta M (1947) Cinchonas del Ecuador. Universidad Central de Ecuador, Quito, p 226

Aguilar R, Quesada M, Ashworth L, Herrerias-Diego Y, Lobo J (2008) Genetic consequences of habitat fragmentation in plant populations: 
susceptible signals in plant traits and methodological approaches. Mol Ecol 17:5177-5188

Altshuler DL (2003) Flower color, hummingbird pollination, and habitat irradiance in four neotropical forests. Biotropica 35:344-355

Andersson L (1998) A revision of the genus Cinchona (RubiaceaeCinchoneae). Mem New York Bot Gard 80:1-75

Arias JC (2017) Cortezas de esperanza. Archivo Histórico de Loja, Municipio de Loja

Armijos-González R, Pérez-Ruiz C (2016) In vitro germination and shoot proliferation of the threatened species Cinchona officinalis L (Rubiaceae). J For Res 27:1229-1236

Bandelt H-J, Forster P, Röhl A (1999) Median-joining networks for inferring intraspecific phylogenies. Mol Biol Evol 16:37-48

Barton NH, Slatkin M (1986) A quasi-equilibrium theory of the distribution of rare alleles in a subdivided population. Heredity 56:409-415

Beck EH, Richter M (2008) Ecological aspects of a biodiversity hotspot in the Andes of southern Ecuador. In: Gradstein SR, Homeier J, Gansert D (eds) The tropical mountain forest - patterns and processes in a biodiversity hotspot. Göttingen Centre for Biodiversity and Ecology, Göttingen, pp 197-219

Brako L, Zarucchi JL (1993) Catalogue of the flowering plants and gymnosperms of Peru. Missouri Botanical Garden.

Brehm G et al (2008) Mountain rainforests in southern Ecuador as a hotspot of biodiversity - limited knowledge and diverging patterns. In: Beck E, Bendix J, Kottke I, Makeschin F, Mosandl R (eds) Gradients in a tropical mountain ecosystem of Ecuador. Springer, Berlin, pp 15-23

Broadbent EN et al (2008) Forest fragmentation and edge effects from deforestation and selective logging in the Brazilian Amazon. Biol Conserv 141:1745-1757

Cascante A, Quesada M, Lobo JJ, Fuchs EA (2002) Effects of dry tropical forest fragmentation on the reproductive success and genetic structure of the tree Samanea saman. Conserv Biol 16:137-147

Chakraborty R, Jin L (1992) Heterozygote deficiency, population substructure and their implications in DNA fingerprinting. Hum Genet 88:267-272

Chapuis MP, Estoup A (2007) Microsatellite null alleles and estimation of population differentiation. Mol Biol Evol 24:621-631

Coates DJ, Carstairs S, Hamley VL (2003) Evolutionary patterns and genetic structure in localized and widespread species in the Stylidium caricifolium complex (Stylidiaceae). Am J Bot 90:9971008

Cornuet JM, Luikart G (1996) Description and power analysis of two tests for detecting recent population bottlenecks from allele frequency data. Genetics 144:2001-2014

Crawford MJ (2016) The Andean Wonder Drug: Cinchona Bark and Imperial Science in the Spanish Atlantic, 1630-1800. University of Pittsburgh Press, USA.

Curto MA et al (2013) Evaluation of microsatellites of Catha edulis (qat; Celastraceae) identified using pyrosequencing. Biochem System Ecol 49:1-9

Cuvi N (2011) The Cinchona Program (1940-1945): science and imperialism in the exploitation of a medicinal plant. Dynamis 31:183-206

Deck LMG et al (2016) New microsatellite markers for two sympatric tinamou species, the Ornate Tinamou (Nothoprocta ornata) and Darwin's Nothura (Nothura darwinii). Avian Biol Res 9:139-146

Di Rienzo A et al (1994) Mutational processes of simple-sequence repeat loci in human populations. Proc Natl Acad Sci USA 91:3166-3170

Doyle JJ, Doyle JL (1987) A rapid DNA isolation procedure for small quantities of fresh leaf tissue. Phytochem Bull 19:11-15

Evanno G, Regnaut S, Goudet J (2005) Detecting the number of clusters of individuals using the software STRUCTURE: a simulation study. Mol Ecol 14:2611-2620

Falush D, Stephens M, Pritchard JK (2003) Inference of population structure using multilocus genotype data: linked loci and correlated allele frequencies. Genetics 164:1567-1587
Fernández-M JF, Sork VL (2007) Genetic variation in fragmented forest stands of the Andean oak Quercus humboldtii Bonpl. (Fagaceae). Biotropica 39:72-78

Garmendia A (2017) Historia de la cascarilla. In: Arias JC (ed) Cortezas de esperanza. Archivo Histórico de Loja, Municipio de Loja, pp 359-377

Garza JC, Williamson EG (2001) Detection of reduction in population size using data from microsatellite loci. Mol Ecol 10:305-318

Gentry AH (1982) Neotropical floristic diversity: phytogeographical connections between Central and South America, Pleistocene climatic fluctuations, or an accident of the Andean orogeny? Ann Miss Bot Gard 69:557-593

Glaubitz JC (2004) CONVERT: A user-friendly program to reformat diploid genotypic data for commonly used population genetic software packages. Mol Ecol Notes 4:309-310

Goudet F (2001) FSTAT, a program to estimate and test gene diversities and fixation indices (version 2.9.3). J Hered 86:485-486

Goudet J, Jombart T (2015) hierfstat: Estimation and Tests of Hierarchical F-Statistics. R package version 0.04-22. https://CRAN.R-project. org/package=hierfstat. Accessed 5 Sept 2019.

Gray J (1738) An account of the Peruvian or Jesuits bark, by Mr. John Gray, F. R. S. now at Cartagena in the Spanish West-Indies; extracted from some papers given him by Mr. William Arrot, a Scotch surgeon, who had gather'd it at the place where it grows in Peru. Phil Trans 40:81-86

Guáman V et al (2017) Multiplicación sexual y asexual de Cinchona officinalis L. con fines de conservación de la especie, en la provincia de Loja. In: Arias JC (ed) Cortezas de esperanza. Archivo Histórico de Loja, Municipio de Loja, pp 322-332

Guillot G, Rousset F (2013) Dismantling the Mantel tests. Methods Ecol Evol 4:336-344

Hamrick JL, Murawski DA (1990) The breeding structure of tropical tree populations. Plant Species Biol 5:157-165

Hansen MC et al (2013) High-resolution global maps of 21st-century forest cover change. Science 342:850-853

Hedrick PW (2005) A standardized genetic differentiation measure. Evolution 59:1633-1638

Hodge WH (1948) Wartime cinchona procurement in Latin America. Econ Bot 2:229-257

Hubisz MJ, Falush D, Stephens M, Pritchard JK (2009) Inferring weak population structure with the assistance of sample group information. Mol Ecol Resour 9:1322-1332

Hughes C, Eastwood R (2006) Island radiation on a continental scale: exceptional rates of plant diversification after uplift of the Andes. Proc Natl Acad Sci USA 103:10334-10339

Inza MV, Zelener N, Fornes L, Gallo LA (2012) Effect of latitudinal gradient and impact of logging on genetic diversity of Cedrela lilloi along the Argentine Yungas Rainforest. Ecol Evol 2:2722-2736

IUCN (2018) Red list of threatened species. http://www.iucnredlist.org/. Accessed 20 November 2018

Jaramillo-Arango J (1947) A critical review of the basic facts in the history of Cinchona. J Linn Soc Bot 53:272-311

Jørgensen PM, Ulloa C, Madsen JE, Valencia R (1995) A floristic analysis of the high Andes of Ecuador. In: Churchill SP, Balsley H, Forero E, Luteyn JL (eds) Biodiversity and conservation of neotropical montane forests. New York Botanical Garden, pp 221-237

Jost L (2008) $\mathrm{G}_{\mathrm{ST}}$ and its relatives do not measure differentiation. Mol Ecol 17:4015-4026

Kang M, Wang J, Huang H (2008) Demographic bottlenecks and low gene flow in remnant populations of the critically endangered Berchemiella wilsonii var. pubipetiolata (Rhamnaceae) inferred from microsatellite markers. Conserv Genet 9:191-199

Kearse M, Moir R, Wilson A, Stones-Havas S, Cheung M, Sturrock S, Buxton S, Cooper A, Markowitz S, Duran C, Thierer T, Ashton B, Meintjes P, Drummond A (2012) Geneious Basic: an integrated and 
extendable desktop software platform for the organization and analysis of sequence data. Bioinformatics 28:1647-1649

Kimura M, Crow JF (1964) The number of alleles that can be maintained in a finite population. Genetics 49:725-738

Kramer AT, Ison JL, Ashley MV, Howe HF (2008) The paradox of forest fragmentation genetics. Conserv Biol 22:878-885

Kreft H, Jetz W (2007) Global patterns and determinants of vascular plant diversity. Proc Natl Acad Sci USA 104:5925-5930

Lambin EF, Geist HJ, Lepers E (2003) Dynamics of land-use and landcover change in tropical regions. Ann Rev Environ Resour 28:205241

Lander TA, Boshier DH, Harris SA (2010) Fragmented but not isolated: contribution of single trees, small patches and long-distance pollen flow to genetic connectivity for Gomortega keule, an endangered Chilean tree. Biol Conserv 143:2583-2590

Larkin MA et al (2007) Clustal W and Clustal X version 2.0. Bioinformatics 23:2947-2948

Leng L, Zhang DX (2011) Measuring population differentiation using $\mathrm{G}_{\mathrm{ST}}$ or D? A simulation study with microsatellite DNA markers under a finite island model and nonequilibrium conditions. Mol Ecol 20:2494-2509

Lindberg AB, Olesen JM (2001) The fragility of extreme specialization: Passiflora mixta and its pollinating hummingbird Ensifera ensifera. J Trop Ecol 17:323-329

Lowe AJ, Boshier D, Ward BCFE, Navarro C (2005) Genetic resource impacts of habitat loss and degradation; reconciling empirical evidence and predicted theory for neotropical trees. Heredity 95:255273

Lowe AJ, Cavers S, Boshier D, Breed MF, Hollingsworth PM (2015) The resilience of forest fragmentation genetics - no longer a paradox we were just looking in the wrong place. Heredity 115:97-99

Luikart G, Cornuet JM (1998) Empirical evaluation of a test for identifying recently bottlenecked populations from allele frequency data. Conserv Biol 12:228-237

Luikart G, Allendorf FW, Cornuet JM, Sherwin WB (1998) Distortion of allele frequency distributions provides a test for recent population bottlenecks. J Hered 89:238-247

Macedo MN, DeFries R, Morton DC, Stickler CM, Galford GL, Shimabukuro YE (2012) Decoupling of deforestation and soy production in the southern Amazon during the late 2000s. Proc Natl Acad Sci USA 109:1341-1346

Magrach A, Larrinaga AR, Santamaría L (2012) Effects of matrix characteristics and interpatch distance on functional connectivity in fragmented temperate rainforests. Conserv Biol 26:238-247

Martin WE, Gandara JA (1945) Alkaloid content of Ecuadoran and other American cinchona barks. Bot Gaz 107:184-199

Meirmans PG (2006) Using the AMOVA framework to estimate a standardized genetic differentiation measure. Evolution 60:2399-2402

Meirmans PG, Hedrick PW (2011) Assessing population structure: $F_{\text {ST }}$ and related measures. Mol Ecol Resour 11:5-18

Menz MHM, Phillips RD, Winfree R, Kremen C, Aizen MA, Johnson SD, Dixon KW (2011) Reconnecting plants and pollinators: challenges in the restoration of pollination mutualisms. Trends Plant Sci $16: 4-12$

Murcia C (1996) Forest fragmentation and the pollination of neotropical plants. In: Schelhas J, Greenberg R (eds) Forest patches in tropical landscapes. Island Press, pp 19-36

Myers N, Mittermeier RA, Mittermeier CG, da Fonseca GAB, Kent J (2000) Biodiversity hotspots for conservation priorities. Nature 403:853-858

Nason JD, Hamrick JL (1997) Reproductive and genetic consequences of forest fragmentation: two case studies of Neotropical canopy trees. J Hered 88:264-276

Nei M (1973) Analysis of gene diversity in subdivided populations. Proc Natl Acad Sci USA 70:3321-3323
Nei M, Tajima F, Tateno Y (1983) Accuracy of estimated phylogenetic trees from molecular data. II. Gene frequency data. J Mol Evol 19: $153-170$

Neigel JE (2002) Is $\mathrm{F}_{\mathrm{ST}}$ obsolete? Conserv Genet 3:167-173

Oetting WS, Lee HK, Flanders DJ, Wiesner GL, Sellers TA, King RA (1995) Linkage analysis with multiplexed short tandem repeat polymorphisms using infrared fluorescence and M13 tailed primers. Genomics 30:450-458

Ohta T, Kimura M (1973) A model of mutation appropriate to estimate the number of electrophoretically detectable alleles in a finite population. Genet Res 22:201-204

Oksanen J et al (2019) vegan: Community Ecology Package. R package version 2:5-5 https://CRAN.R-project.org/package=vegan. Accessed 5 Sept 2019

Peakall R, Smouse PE (2006) GENALEX 6: Genetic Analysis in Excel. Population genetic software for teaching and research. Mol Ecol Notes 6:288-295

Peakall R, Smouse PE (2012) GenAlEx 6.5: genetic analysis in Excel. Population genetic software for teaching and research - an update. Bioinformatics 28:2537-2539

Piry S, Luikart G, Cornuet JM (1999) BOTTLENECK: A computer program for detecting recent reductions in the effective population size using allele frequency data. J Hered 90:502-503

Prieto-Torres DA, Cuervo AM, Bonaccorso E (2018) On geographic barriers and Pleistocene glaciations: Tracing the diversification of the Russet-crowned Warbler (Myiothlypis coronata) along the Andes. PLoS ONE 13:e0191598. https://doi.org/10.1371/journal. pone. 0191598

Pritchard JK, Stephens M, Donnelly P (2000) Inference of population structure using multilocus genotype data. Genetics 155:945-959

Provan J, Powell W, Hollingsworth PM (2001) Chloroplast microsatellites: new tools for studies in plant ecology and evolution. Trends Ecol Evol 16:142-147

R Development Core Team (2004) R: A language and environment for statistical computing. R Foundation for Statistical Computing, Vienna

Raymond M, Rousset F (1995) GENEPOP (version 1.2): population genetics software for exact tests and ecumenicism. J Hered 86: 248-249

Renner SS (1998) Effects of habitat fragmentation on plant pollinator interactions in the tropics. In: Newbery DM, HHT P, Brown ND (eds) Dynamics of tropical communities: 37 th symposium of the British Ecological Society. Blackwell Science, pp 339-360

Richter M (2003) Using epiphytes and soil temperatures for eco-climatic interpretations in Southern Ecuador. Erdkunde 57:161-181

Richter M, Moreira-Muñoz A (2005) Heterogeneidad climática y diversidad de la vegetación en el sur de Ecuador: un método de fitoindicación. Rev Peru Biol 12:217-238

Richter M, Diertl KH, Emck P, Peters T, Beck E (2009) Reasons for an outstanding plant diversity in the tropical Andes of Southern Ecuador. Landsc Online 12:1-35 https://www.landscapeonline.de/ 1030971o200912. Accessed 5 Sept 2019

Romero-Saritama JM, Munt DD (2017) Almacenamiento y morfología de semillas. Universidad Técnica Particular de Loja, Loja, pp 137 138

Rosenberg NA (2004) DISTRUCT: a program for the graphical display of population structure. Mol Ecol Notes 4:137-138

Rousset F (2008) GENEPOP'007: a complete reimplementation of the GENEPOP software for Windows and Linux. Mol Ecol Resour 8: 103-106

Sazima I, Buzato S, Sazima M (1996) An assemblage of hummingbirdpollinated flowers in a montane forest in southeastern Brazil. Bot Acta 109:149-160

Shaw J et al (2005) The tortoise and the hare II: relative utility of 21 noncoding chloroplast DNA sequences for phylogenetic analysis. Am J Bot 92:142-166 
Spencer CC, Neigel JE, Leberg PL (2000) Experimental evaluation of the usefulness of microsatellite DNA for detecting demographic bottlenecks. Mol Ecol 9:1517-1528

Stouffer PC, Bierregaard RO Jr (1995) Effects of forest fragmentation on understory hummingbirds in Amazonian Brazil. Conserv Biol 9: 1085-1094

Takezaki N, Nei M (2008) Empirical tests of the reliability of phylogenetic trees constructed with microsatellite DNA. Genetics 178:385392

Takezaki N, Nei M, Tamura K (2010) POPTREE2: Software for constructing population trees from allele frequency data and computing other population statistics with Windows interface. Mol Biol Evol 27:747-752

Tapia-Armijos MF, Homeier J, Espinosa CI, Leuschner C, de la Cruz M (2015) Deforestation and forest fragmentation in South Ecuador since the 1970s - losing a hotspot of biodiversity. PLoS ONE 10: e0133701. https://doi.org/10.1371/journal.pone.0133701

Tropicos (2018) Cinchona. http://www.tropicos.org/Name/40009072? projectid $=34$. Accessed 19 December 2018

Vittoz P, Engler R (2007) Seed dispersal distances: a typology based on dispersal modes and plant traits. Bot Helv 117:109-124
Vranckx G, Jacquemyn H, Muys B, Honnay O (2012) Meta-analysis of susceptibility of woody plants to loss of genetic diversity through habitat fragmentation. Conserv Biol 26:228-237

Waits LP, Luikart G, Taberlet P (2001) Estimating the probability of identity among genotypes in natural populations: cautions and guidelines. Mol Ecol 10:249-256

Weising K, Nybom H, Wolff K, Kahl G (2005) DNA fingerprinting in plants: principles, methods, and applications, 2nd edn. CRC Press, $p$ 270

Wright S (1951) The genetical structure of populations. Ann Eugen 15: 323-354

Wright S (1965) The interpretation of population structure by F-statistics with special regard to systems of mating. Evolution 19:395-420

Young A, Boyle T, Brown T (1996) The population genetic consequences of habitat fragmentation for plants. Trends Ecol Evol 10:413-418

Publisher's note Springer Nature remains neutral with regard to jurisdictional claims in published maps and institutional affiliations. 